\title{
Article
}

\section{Valorization of Vine Prunings by Slow Pyrolysis in a Fixed-Bed Reactor}

\author{
Suzana Ioana Calcan ${ }^{1,2}$, Oana Cristina Pârvulescu ${ }^{1, *}$, Violeta Alexandra Ion ${ }^{3, *}$, Cristian Eugen Răducanu ${ }^{1}$, \\ Liliana Bădulescu ${ }^{3}{ }^{\circledR}$, Tănase Dobre ${ }^{1}$, Diana Egri ${ }^{1}$, Andrei Moț ${ }^{3}$, Vlad Popa ${ }^{3}$ and Mihaela Emanuela Crăciun ${ }^{4}$ \\ 1 Chemical and Biochemical Engineering Department, University Politehnica of Bucharest, 1-6 Gheorghe Polizu \\ Str., 011061 Bucharest, Romania; suzanastancescu@yahoo.com (S.I.C.); cristianrdcn1@yahoo.com (C.E.R.); \\ tghdobre@gmail.com (T.D.); diana_egri@yahoo.com (D.E.) \\ 2 Scient Research Center for Instrumental Analysis, 1 Petre Ispirescu Str., 77167 Tancabesti, Romania \\ 3 Research Center for Studies of Food and Agricultural Products Quality, University of Agronomic Sciences and \\ Veterinary Medicine of Bucharest, 59 Marasti Blvd., 011464 Bucharest, Romania; lilib_20@yahoo.com (L.B.); \\ mot_andrei@yahoo.com (A.M.); popa.ivlad@yahoo.com (V.P.) \\ 4 Analytical Chemistry and Environmental Engineering Department, University Politehnica of Bucharest, \\ 1-6 Gheorghe Polizu Str., 011061 Bucharest, Romania; craciun.me@gmail.com \\ * Correspondence: oana.parvulescu@yahoo.com (O.C.P.); violeta.ion.phd@gmail.com (V.A.I.)
}

Citation: Calcan, S.I.; Pârvulescu, O.C.; Ion, V.A.; Răducanu, C.E.; Bădulescu, L.; Dobre, T.; Egri, D.; Moț, A.; Popa, V.; Crăciun, M.E. Valorization of Vine Prunings by Slow Pyrolysis in a Fixed-Bed Reactor. Processes 2022, 10,37. https:// doi.org/10.3390/pr10010037

Academic Editor: Davide Dionisi

Received: 15 November 2021

Accepted: 22 December 2021

Published: 24 December 2021

Publisher's Note: MDPI stays neutral with regard to jurisdictional claims in published maps and institutional affiliations.

Copyright: (C) 2021 by the authors. Licensee MDPI, Basel, Switzerland. This article is an open access article distributed under the terms and conditions of the Creative Commons Attribution (CC BY) license (https:// creativecommons.org/licenses/by/ $4.0 /)$.

\begin{abstract}
The paper aimed at studying the slow pyrolysis of vine pruning waste in a fixed bed reactor and characterizing the pyrolysis products. Pyrolysis experiments were conducted for $60 \mathrm{~min}$, using $\mathrm{CO}_{2}$ as a carrier gas and oxidizing agent. The distribution of biochar and bio-oil was dependent on variations in heat flux $\left(4244-5777 \mathrm{~W} / \mathrm{m}^{2}\right), \mathrm{CO}_{2}$ superficial velocity $(0.004-0.008 \mathrm{~m} / \mathrm{s})$, and mean size of vegetal material $(0.007-0.011 \mathrm{~m})$. Relationships among these factors and process performances in terms of yields of biochar (0.286-0.328) and bio-oil (0.260-0.350), expressed as ratio between the final mass of pyrolysis product and initial mass of vegetal material, and final value of fixed bed temperature $\left(401.1-486.5^{\circ} \mathrm{C}\right)$ were established using a $2^{3}$ factorial design. Proximate and ultimate analyses, FT-IR and SEM analyses, measurements of bulk density $\left(0.112 \pm 0.001 \mathrm{~g} / \mathrm{cm}^{3}\right)$, electrical conductivity $(0.55 \pm 0.03 \mathrm{dS} / \mathrm{m}), p H(10.35 \pm 0.06)$, and water holding capacity $(58.99 \pm 14.51 \%)$ were performed for biochar. Water content $(33.2 \pm 1.27 \%)$, density $\left(1.027 \pm 0.014 \mathrm{~g} / \mathrm{cm}^{3}\right), p H(3.34 \pm 0.02)$, refractive index $(1.3553 \pm 0.0027)$, and iodine value $\left(87.98 \pm 4.38 \mathrm{~g} \mathrm{I}_{2} / 100 \mathrm{~g}\right.$ bio-oil $)$ were measured for bio-oil. Moreover, chemical composition of bio-oil was evaluated using GC-MS analysis, with 27 organic compounds being identified.
\end{abstract}

Keywords: bio-oil; biochar; pyrolysis; vine prunings

\section{Introduction}

In the current context of the fossil fuel crisis and environmental pollution, clean and renewable energy resources have become an increasingly studied alternative [1-5]. Due to its low cost, abundance, and carbon neutrality, residual lignocellulosic biomass represents an attractive renewable resource for producing biofuels and chemicals [1,6]. Lignocellulosic biomass, which is mainly composed of polysaccharides [hemicellulose (15-40\%) and cellulose (25-50\%)] and aromatic polymers [lignin (10-40\%)], can be valorized using different thermo-chemical technologies, e.g., combustion, pyrolysis, gasification, hydrothermal liquefaction, or biochemical routes, including fermentation and anaerobic digestion [3-12]. Among them, pyrolysis is a very promising technology which involves lower energy consumption and costs than other conversion routes as well as high addedvalue products $[3,5,7,11]$.

Pyrolysis consists in thermal decomposition of an organic feedstock in an oxygenlimited environment resulting in biochar and volatiles. Volatile compounds are further condensed producing permanent gases and a pyrolytic liquid (bio-oil) containing 15-35\% 
water [13]. Pyrolysis is generally performed in the presence of an inert $\left(\mathrm{Ar}, \mathrm{N}_{2}\right)$ or oxidizing $\left(\mathrm{CO}_{2}\right.$, steam) carrier gas [14-16]. Depending on heating rate $\left(r_{h}\right)$, residence time of volatiles $\left(\tau_{r}\right)$, and process final temperature $(t)$, the pyrolysis can be slow $\left(r_{h}=0.1-1{ }^{\circ} \mathrm{C} / \mathrm{s}\right.$, $\left.\tau_{r}=10-100 \mathrm{~min}, t=300-700{ }^{\circ} \mathrm{C}\right)$, rapid $\left(r_{h}=10-200^{\circ} \mathrm{C} / \mathrm{s}, \tau_{r}=0.5-5 \mathrm{~s}, t=400-600{ }^{\circ} \mathrm{C}\right)$, or flash $\left(r_{h} \geq 1000{ }^{\circ} \mathrm{C} / \mathrm{s}, \tau_{r}<0.5 \mathrm{~s}, t=800-1000{ }^{\circ} \mathrm{C}\right)[1,8,9,17,18]$.

Pyrolysis products are obtained from primary decomposition reactions of organic feedstock (mainly of hemicellulose, cellulose, and lignin) and secondary decomposition reactions of primary products (e.g., gasification (reforming with $\mathrm{CO}_{2}, \mathrm{H}_{2}$, and steam) of condensable organic volatiles and biochar carbon, cracking of condensable organic volatiles, biochar aromatization) into low-molecular weight gases and biochar carbon [13-16,19]. Distribution, composition, and properties of biochar, bio-oil, and pyrolytic gases depend on different factors, e.g., type of pyrolysis and related operating parameters (heating rate, process final temperature, residence time of pyrolysis volatiles or flow rate of carrier gas), type, size, and pretreatment of organic feedstock, type and flow rate of carrier gas, reactor design $[2-5,9-23]$. Slow pyrolysis produces higher yields of biochar $(30-60 \%)$, whereas less biochar (10-25\%) and more bio-oil (60-75\%) are commonly obtained by fast pyrolysis $[7-9,17]$. Lower biochar yields are produced at higher levels of heating rate and process final temperature $[4,9,21]$. Moreover, higher levels of final temperature generally lead to higher levels of ash and carbon content, $\mathrm{pH}$, specific surface area, porosity, electrical conductivity, aromaticity, and hydrophobicity of biochar as well as to a decrease in its water-holding capacity and number of functional groups containing $\mathrm{O}$ and $\mathrm{N}[20,24]$. A lower flow rate of an oxidizing carrier gas (e.g., steam, $\mathrm{CO}_{2}$ ) leads to a longer residence time of pyrolysis volatiles in the reaction medium, which can favor secondary reactions of reforming and cracking, usually resulting in lower bio-oil yield and higher production of non-condensable gases [13]. A higher lignin content in the feedstock generally leads to higher biochar yield and biochar ash content [18].

Composition and properties of pyrolysis products determine their applications. Biochar is useful as a renewable fuel or for other applications, e.g., soil amendment, sorption of contaminants from soil, water, and air, production of activated carbon and catalysts, $\mathrm{CO}_{2}$ sequestration, $\mathrm{H}_{2}$ storage, composting $[9,19,23-26]$. Biochar used as a soil amendment can contribute to enhanced soil $\mathrm{C}$ sequestration, reduced greenhouse gas emissions and nutrient leaching, improved soil fertility and health $[24,26]$. An increase in soil fertility determines a diminished fertilizer input as well as enhanced crop productivity and thus supplementary $\mathrm{CO}_{2}$ consumption, resulting in agronomic, environmental, and economic benefits. Bio-oil and pyrolysis gases can be directly used for heat and electricity generation and they are also a valuable source of chemicals $[4,17,27]$. Bio-oil contains various organic compounds, e.g., alcohols, aldehydes, ketones, carboxylic acids, carbohydrates, esters, ethers, furans, nitrogen-containing compounds, mono- and polycyclic aromatic hydrocarbons $[13,17]$. Pyrolysis bio-oil has a high oxygen content, which determines its instability, low heating values, and high acidity [1]. After a suitable upgradation, pyrolysis bio-oil can be blended with diesel or gasoline $[7,28]$.

This paper focuses on the study of fixed bed pyrolysis of vine pruning waste under $\mathrm{CO}_{2}$ atmosphere and the characterization of biochar and bio-oil. We predict the effects of process independent variables, i.e., heat flow rate, $\mathrm{CO}_{2}$ superficial velocity, and vine waste size, on the process performances in terms of final levels of mean bed temperature, biochar and bio-oil yields.

\section{Materials and Methods}

\subsection{Materials}

Vegetal material consisted in vine prunings supplied by University of Agronomic Sciences and Veterinary Medicine of Bucharest (USAMV), PIETROASA-ISTRITA Research Station for Viticulture and Pomiculture, Dealu Mare Vineyard, Muntenia and Oltenia Hills Region. Vine waste was cut with pruning shears resulting in cylindrical particles. Fine and coarse particles, having diameter $\times$ height of about $3.5 \mathrm{~mm} \times 20 \mathrm{~mm}$ and $7.0 \mathrm{~mm} \times 20 \mathrm{~mm}$, 
corresponding to volumes of $192 \mathrm{~mm}^{3}$ and $770 \mathrm{~mm}^{3}$ (volume equivalent diameter of $0.007 \mathrm{~m}$ and $0.011 \mathrm{~m}$ ), respectively, were selected for experimental study (Figure 1). $\mathrm{CO}_{2}$ (purity $>99.9$ ) was used both as a carrier gas and an oxidizing agent in the pyrolysis process.

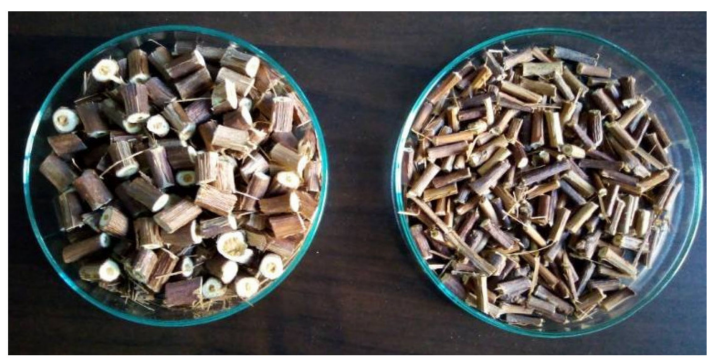

Figure 1. Coarse and fine chopped vine prunings.

\subsection{Equipment and Procedures}

Slow pyrolysis of vine waste was conducted at University POLITEHNICA of Bucharest (UPB), Chemical and Biochemical Department, in the laboratory setup shown in Figure 2. The vegetal material was fed in a ceramic column (1), $0.030 \mathrm{~m}$ internal diameter $(D)$ and $0.500 \mathrm{~m}$ height, which was set into an autoclaved cellular concrete (ACC) support (2). The column wall (4 mm thickness), thermally isolated by a glass cylinder (3), was heated by an electric resistance (4), which was powered by an autotransformer (5). The pyrolysis column was placed on a melamine board (6) fixed inside a laboratory niche.

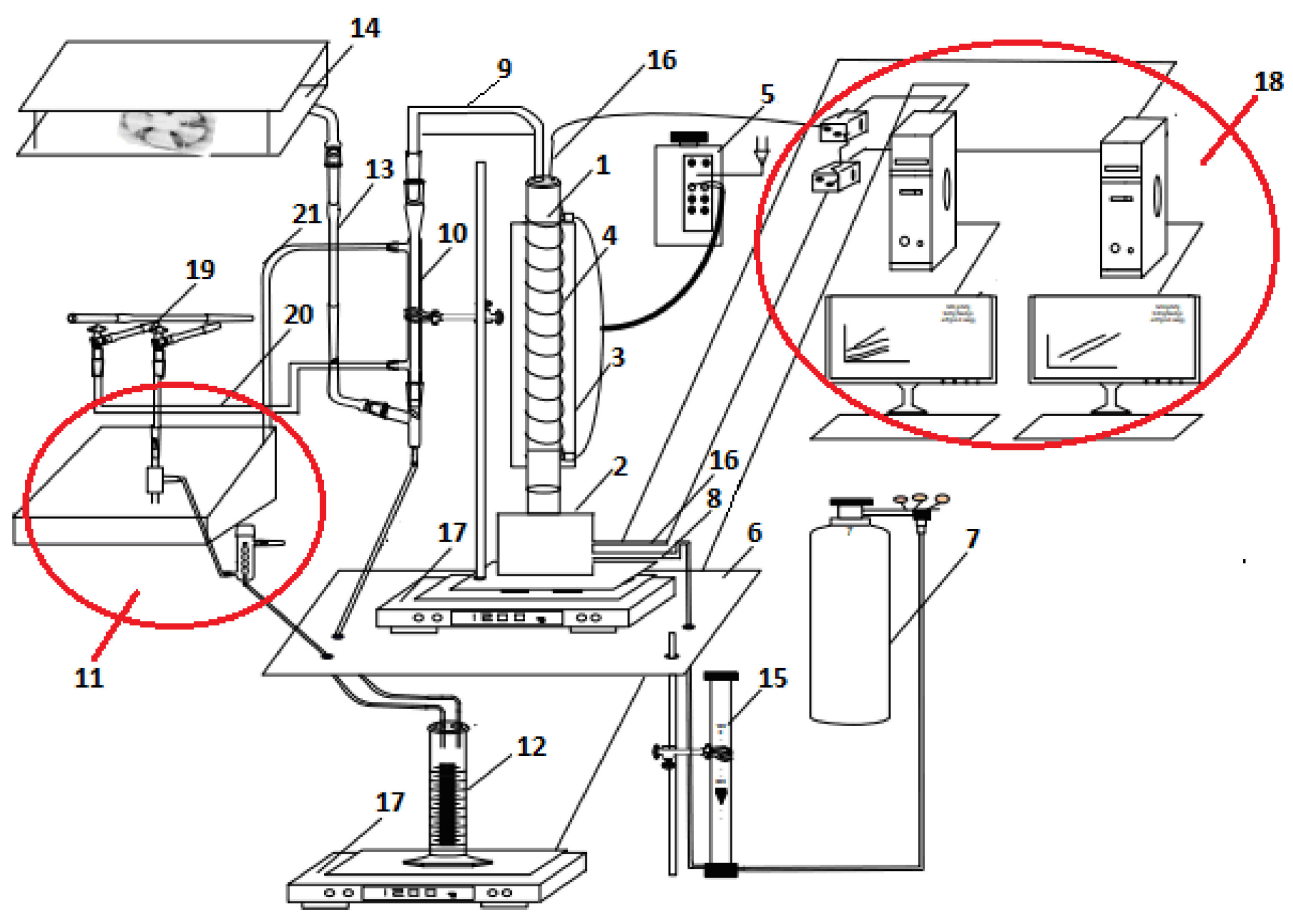

Figure 2. Cont. 


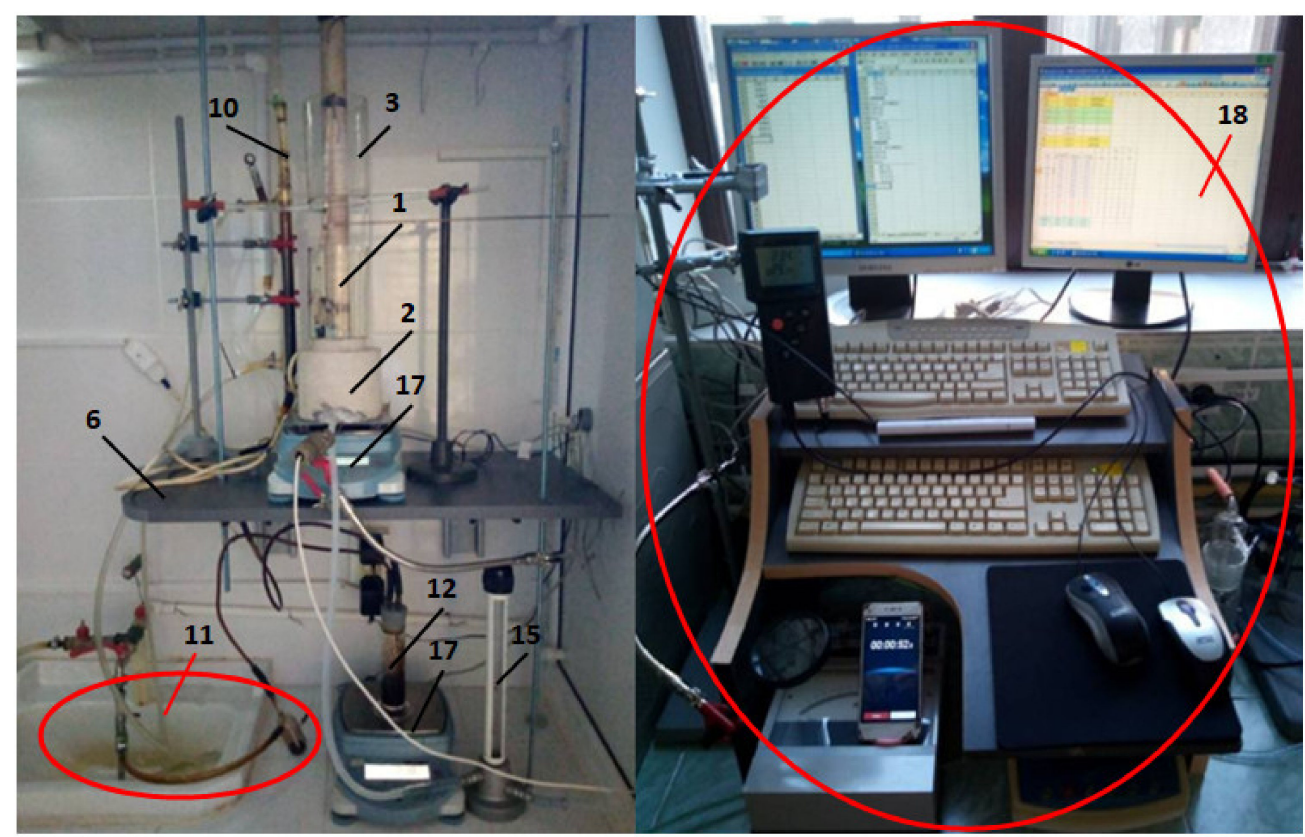

Figure 2. Experimental setup: (1) pyrolysis column; (2) autoclaved cellular concrete (ACC) support; (3) glass cylinder (jacket); (4) electric resistance; (5) autotransformer; (6) melamine board; (7) $\mathrm{CO}_{2}$ tank; (8) $\mathrm{CO}_{2}$ feed pipe; (9) pipe collecting volatile products; (10) Liebig condenser; (11) laboratory vacuum system; (12) oil collector; (13) pipe collecting non-condensable gases; (14) exhaust hood; (15) flow-meter; (16) thermocouples; (17) electronic balances; (18) data acquisition system; (19) water source; (20) cold water (thermal agent in condenser) feed pipe; (21) water outlet pipe.

$\mathrm{CO}_{2}$ from a gas tank (7) was fed into the pyrolysis column through a pipe (8), upflowed through the fixed bed material, and was discharged through a collecting pipe (9) along with the volatiles produced during the pyrolysis. The mixture of non-condensable gases and vapour was cooled in a Liebig condenser (10), resulting in a pyrolytic liquid and non-condensable gases. Evacuation and condensation of volatile compounds were performed in the presence of a laboratory vacuum system (11). The pyrolysis liquid was collected in a graduated cylinder (12), whereas the non-condensable gases were discharged through a pipe (13) and an exhaust hood (14).

$\mathrm{CO}_{2}$ volumetric flow rate, $G_{V}\left(\mathrm{~m}^{3} / \mathrm{s}\right)$, was measured by a flow-meter (15). The temperatures in the centre of the material bed $\left(t_{c}\right)$ and at the wall $\left(t_{w}\right)$ were measured by the thermocouples (16). The masses of solid $(m)$ and liquid $\left(m_{L}\right)$ were monitored and recorded by the electronic balances (17). The values of temperature and mass were collected continuously by a data acquisition system (18). Pyrolysis experiments were conducted for $\tau_{f}=60 \mathrm{~min}$ at $20^{\circ} \mathrm{C}$ and $1 \mathrm{~atm}$.

\subsection{Independent and Dependent Process Variables}

Heat flux, $q\left(\mathrm{~W} / \mathrm{m}^{2}\right), \mathrm{CO}_{2}$ superficial velocity, $w(\mathrm{~m} / \mathrm{s})$, defined by Equation (1), and mean diameter of vegetal material particle, $d(\mathrm{~m})$, were selected as process independent variables (factors). According to a $2^{3}$ factorial design, eight experimental runs (1-8 in Table 1) were conducted at two levels of process factors $\left(4244 \mathrm{~W} / \mathrm{m}^{2}\right.$ and $5777 \mathrm{~W} / \mathrm{m}^{2}$, $0.004 \mathrm{~m} / \mathrm{s}$ and $0.008 \mathrm{~m} / \mathrm{s}, 0.007 \mathrm{~m}$ and $0.011 \mathrm{~m})$. Specific masses of vegetal material bed and pyrolysis liquid (bio-oil), $m / m_{0}$ and $m_{L} / m_{0}$, where $m_{0}(\mathrm{~g})$ represents the initial mass of vine waste, and mean logarithmic temperature of vegetal material bed, $t_{m}\left({ }^{\circ} \mathrm{C}\right)$, defined by Equation (2), were process-dependent variables (responses).

$$
w=\frac{4 G_{V}}{\pi D^{2}}
$$




$$
t_{m}=\frac{t_{w}-t_{c}}{\ln \left(\frac{t_{w}}{t_{c}}\right)}
$$

Table 1. Levels of process factors and performances.

\begin{tabular}{|c|c|c|c|c|c|c|c|c|c|}
\hline Exp. & $\begin{array}{c}q \\
\left(W / m^{2}\right)\end{array}$ & $\begin{array}{c}w \\
(\mathrm{~m} / \mathrm{s})\end{array}$ & $\begin{array}{c}d \\
(\mathrm{~m})\end{array}$ & $x_{1}$ & $x_{2}$ & $x_{3}$ & $m_{f} / m_{0}$ & $m_{L f} / m_{0}$ & $\begin{array}{c}t_{m f} \\
\left({ }^{\circ} \mathrm{C}\right)\end{array}$ \\
\hline 1 & 4244 & 0.004 & 0.007 & -1 & -1 & -1 & 0.312 & 0.278 & 426.6 \\
\hline 2 & 5777 & 0.004 & 0.007 & 1 & -1 & -1 & 0.306 & 0.328 & 473.6 \\
\hline 3 & 4244 & 0.008 & 0.007 & -1 & 1 & -1 & 0.328 & 0.260 & 401.1 \\
\hline 4 & 5777 & 0.008 & 0.007 & 1 & 1 & -1 & 0.324 & 0.346 & 449.2 \\
\hline 5 & 4244 & 0.004 & 0.011 & -1 & -1 & 1 & 0.298 & 0.296 & 406.9 \\
\hline 6 & 5777 & 0.004 & 0.011 & 1 & -1 & 1 & 0.286 & 0.350 & 486.5 \\
\hline 7 & 4244 & 0.008 & 0.011 & -1 & 1 & 1 & 0.314 & 0.328 & 406.3 \\
\hline 8 & 5777 & 0.008 & 0.011 & 1 & 1 & 1 & 0.310 & 0.304 & 479.1 \\
\hline 9 & 5010 & 0.006 & 0.009 & 0 & 0 & 0 & 0.312 & 0.306 & 438.8 \\
\hline 10 & 5010 & 0.006 & 0.009 & 0 & 0 & 0 & 0.309 & 0.312 & 442.7 \\
\hline 11 & 5010 & 0.006 & 0.009 & 0 & 0 & 0 & 0.305 & 0.314 & 444.2 \\
\hline
\end{tabular}

\subsection{Biochar Characterization}

Biochar samples were sent to the Research Center for Studies of Food and Agricultural Products Quality of USAMV and SCIENT Research Center for Instrumental Analysis for physicochemical characterization. Proximate and ultimate analyses and measurements of bulk density $(B D)$, electrical conductivity $(E C), p H$, and water-holding capacity $(W H C)$ were taken in triplicate. Biochar morphology and surface functional groups were analyzed using scanning electron microscopy (SEM) and Fourier transform infrared (FT-IR) spectroscopy, respectively.

Dry matter content, DM (\%), was determined using a Memmert UN110 oven as follows: the biochar sample was kept at $70{ }^{\circ} \mathrm{C}$ for $1 \mathrm{~h}$ and then at $105^{\circ} \mathrm{C}$ until a constant mass was achieved. Ash content, Ash (\%), was determined by igniting a biochar sample ( $1 \mathrm{~g})$ at $650{ }^{\circ} \mathrm{C}$ for $6 \mathrm{~h}$ in a Nabertherm B150 oven. Volatile matter content, $V M(\%)$, was evaluated using dried biochar samples (after oven drying at $105^{\circ} \mathrm{C}$ ). According to ASTM D5142 [29], the biochar sample was put in a covered crucible, which was placed in the Nabertherm B150 oven. The oven was heated $\left(50{ }^{\circ} \mathrm{C} / \mathrm{min}\right)$ up to $950 \pm 20^{\circ} \mathrm{C}$ and this maximum temperature value was maintained for $7 \mathrm{~min}$. $V M$ was calculated using Equation (3), where $m_{d}(\mathrm{~g})$ is the mass of the oven-dried sample and $m_{V M}(\mathrm{~g})$ is the mass of sample after completion of $V M$ test. Fixed carbon content, FC (\%), was calculated by subtracting Ash and VM from DM (Equation (4)). The results of proximate analysis were expressed on wet basis (wb).

$$
\begin{gathered}
V M=\frac{m_{d}-m_{V M}}{m_{d}} \times 100 \\
F C=D M-A s h-V M
\end{gathered}
$$

For ultimate analysis, amounts of $1-3 \mathrm{mg}$ of biochar were used to determine the percentages of carbon $(C)$, hydrogen $(H)$, nitrogen $(N)$, and sulfur $(S)$. The analysis was performed using a EuroVector EA3100 Elemental Analyzer and cystine as standard reference material. Oxygen content $(O)$ was calculated by difference (Equation (5)). The results of ultimate analysis were expressed on dry, ash-free basis (dafb).

$$
O=100-C-H-N-S
$$

To evaluate bulk density $(B D)$, an oven-dried biochar sample was placed in a glass cylinder. $B D\left(\mathrm{~g} / \mathrm{cm}^{3}\right)$ was calculated with Equation (6), where $m_{c}(\mathrm{~g})$ is the mass of glass 
cylinder, $m_{c+d}(\mathrm{~g})$ the total mass of glass cylinder and dried sample, and $V_{d}\left(\mathrm{~cm}^{3}\right)$ the volume of dried sample.

$$
B D=\frac{m_{c+d}-m_{c}}{V_{d}}
$$

Electrical conductivity $(E C)$ and $p H$ of a suspension obtained by mixing $0.5 \mathrm{~g}$ of biochar with $20 \mathrm{~mL}$ of distilled water for $1 \mathrm{~h}$, using an IKA C-Mag HS7 magnetic homogenizer, were measured with a Mettler Toledo SevenExcellence Multiparameter. To evaluate water holding capacity (WHC), the following steps were performed [30]: (i) $20 \mathrm{~g}$ of biochar sample was placed in a glass recipient with glass wire mesh at the bottom and the recipient was immersed in a glass beaker with water; (ii) after $24 \mathrm{~h}$, the recipient with wet sample was fixed in a larger vessel to drain excess water; (iii) after $6 \mathrm{~h}$, the recipient was weighed and then dried in an oven at $105{ }^{\circ} \mathrm{C}$ until a constant mass was obtained. WHC (\%) was calculated using Equation (7), where $m_{r}(\mathrm{~g})$ is the mass of glass recipient, $m_{r+w}(\mathrm{~g})$ the total mass of glass recipient and wet sample after draining, and $m_{r+d}(\mathrm{~g})$ the total mass of glass recipient and oven-dried sample.

$$
W H C=\frac{m_{r+w}-m_{r+d}}{m_{r+w}-m_{r}} \times 100
$$

Morphology of biochar samples was examined with a Carl Zeiss EVO LS 15 scanning electron microscope. SEM analysis was performed using an electron acceleration of $5 \mathrm{kV}$. Images were obtained at a magnification of $250 \times$. Surface functional groups of vine waste biochar were analyzed with a Frontier MIR/NIR spectrometer (PerkinElmer) at wavenumbers from 4000 to $380 \mathrm{~cm}^{-1}$ using $32 \mathrm{scans} / \mathrm{min}$ at $4 \mathrm{~cm}^{-1}$ spectral resolution.

\subsection{Bio-Oil Characterization}

Bio-oil samples were analyzed at UPB (Analytical Chemistry and Environmental Engineering Department) and SCIENT Research Center for Instrumental Analysis. The water content $(W)$ of the bio-oil obtained in exp. 6 was determined with a TitroLine alpha plus Karl Fischer titrator (Schott Instruments), density $(\rho)$ with an ISOLAB pycnometer $(25 \mathrm{~mL}), \mathrm{pH}$ value with a SevenMulti $\mathrm{pH}$ meter (Mettler Toledo), and refractive index (RI) with a DR-301-95 digital handheld refractometer (Krüss). Iodine value (IV) was determined as follows: a mixture of methanol and chloroform (1:1) was added to the oil sample and then Hanus reagent was added; the mixture was left in the dark for 30 min, then KI was added and titrated with $0.1 \mathrm{~N}$ sodium thiosulfate solution in the presence of starch. All measurements were performed in triplicate.

The chemical composition of bio-oil was evaluated via GC-MS (Perkin Elmer Clarus 680 coupled with Clarus SQ 8T), using an Elite-5MS capillary column (30 m length, $0.25 \mathrm{~mm}$ internal diameter, $0.25 \mu \mathrm{m}$ film thickness, stationary phase of $5 \%$ diphenyl $/ 95 \%$ dimethylpolysiloxane). Helium (99.999\% purity, $1.2 \mathrm{~mL} / \mathrm{min}$ flow rate, $20: 1$ split ratio) was used as a carrier gas. The oven temperature was programmed as follows: $50{ }^{\circ} \mathrm{C}$ (holding time: $1 \mathrm{~min}$ ), then increase by $8{ }^{\circ} \mathrm{C} / \mathrm{min}$ to $315^{\circ} \mathrm{C}$ (holding time: $5 \mathrm{~min}$ ). The injector temperature was set to $300^{\circ} \mathrm{C}$ and the volume injected was $1 \mu \mathrm{L}$. The MS operating conditions were: source temperature of $230^{\circ} \mathrm{C}$, transfer line temperature of $315^{\circ} \mathrm{C}$, electron impact ionization EI+ at $70 \mathrm{eV}$, and a solvent delay of $3 \mathrm{~min}$. The acquisition of mass spectrum for bio-oil components was achieved in the full scan mode with scanned mass range of 30-620 m/z. The identification of compounds was performed using National Institute of Standards and Technology (NIST) MS Search library (version 2.3) with a match criteria of at least 600 . The bio-oil sample was $10 \times$ diluted with methanol and then injected in the GC-MS system. 


\section{Results and Discussion}

\subsection{Experimental Performances of Slow Pyrolysis}

Experimental dynamics of slow pyrolysis, i.e., $m / m_{0}, m_{L} / m_{0}$, and $t_{m}$ vs. time $(\tau)$, are shown in Figures 3-5. Process performances in terms of final values (at $\tau_{f}=60 \mathrm{~min}$ ) of dependent variables $\left(m_{f} / m_{0}=0.286-0.328, m_{L f} / m_{0}=0.260-0.350\right.$, and $\left.t_{m f}=401.1-486.5{ }^{\circ} \mathrm{C}\right)$ are summarized in Table 1 . Depicted and tabulated data indicate, in general, the following issues: (i) values of mean temperature of vegetal material bed $\left(t_{m}\right)$ and specific mass of bio-oil $\left(m_{L} / m_{0}\right)$ are higher and those of specific mass of vine waste $\left(\mathrm{m} / \mathrm{m}_{0}\right)$ are lower at higher level of heat flux $\left(q=5777 \mathrm{~W} / \mathrm{m}^{2}\right)$; (ii) values of $m_{L} / m_{0}$ are higher and those of $m / m_{0}$ are lower at higher level of particle size $(d=0.011 \mathrm{~m})$ and lower level of $\mathrm{CO}_{2}$ superficial velocity $(w=0.004 \mathrm{~m} / \mathrm{s})$; (iii) $t_{m}$ is not affected by $d$, regardless of the level of $w$, whereas the effect of $w$ on $t_{m}$ is negligible for coarse particles $(d=0.011 \mathrm{~m})$; (iv) final values of bed temperature $\left(t_{m f}\right)$ are larger and those of solid specific mass $\left(m_{f} / m_{0}\right)$ are lower at higher levels of $q$ and $d$ as well as at lower level of $w$; (v) final values of bio-oil specific mass $\left(m_{L f} / m_{0}\right)$ are larger at higher levels of $q$ and $d$.
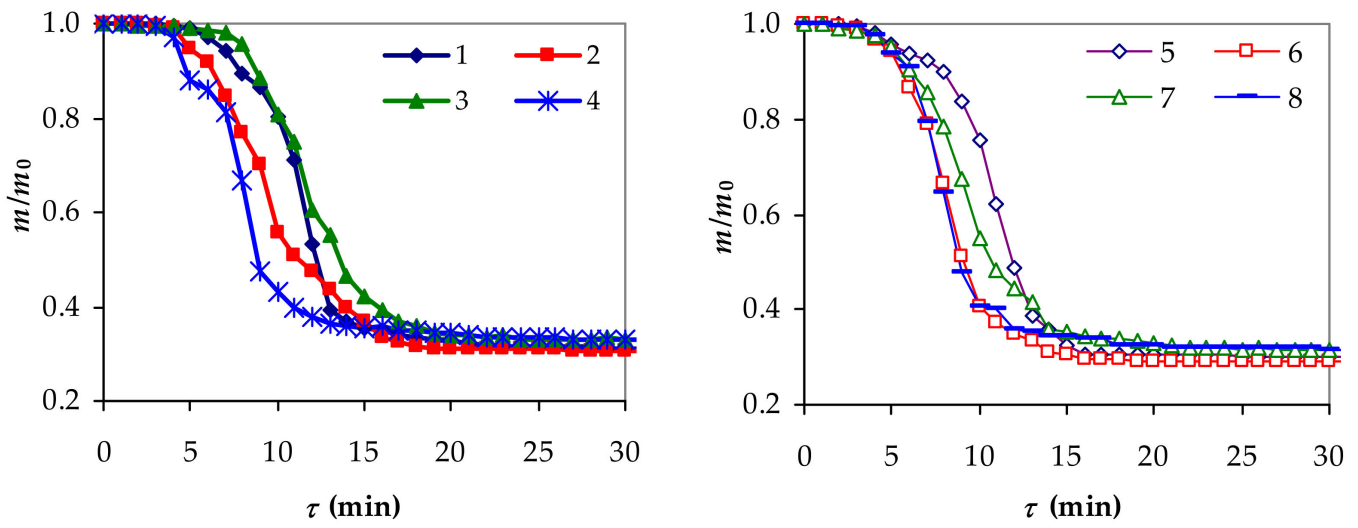

Figure 3. Specific mass of fixed bed vine waste vs. time.
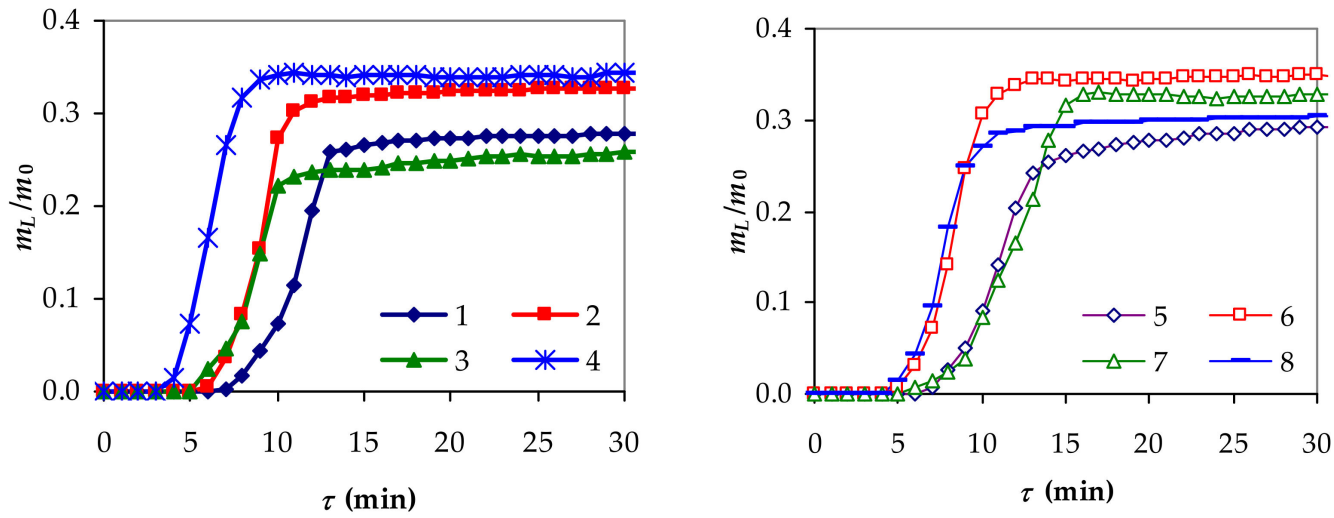

Figure 4. Specific mass of pyrolysis liquid (bio-oil) vs. time. 

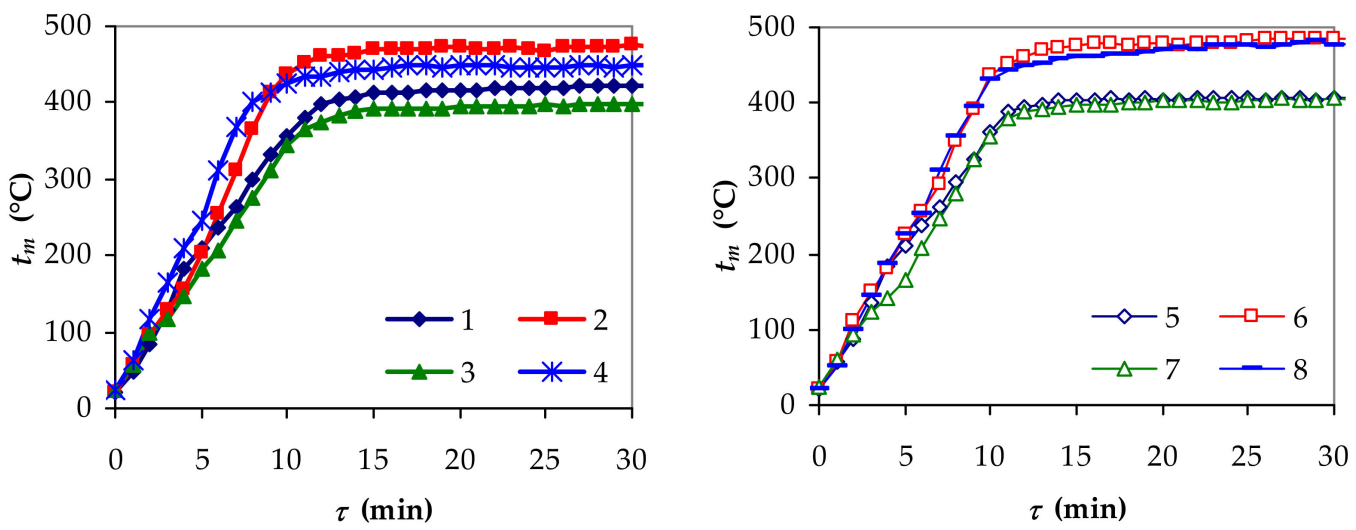

Figure 5. Mean temperature of fixed bed vine waste vs. time.

Decomposition rate of vine waste, $\mathrm{d} \alpha / \mathrm{d} \tau\left(\mathrm{min}^{-1}\right)$, where $\alpha$ represents the conversion of volatiles defined by Equation (8) and $\tau(\mathrm{min})$ the time, is represented depending on mean temperature of fixed bed waste, $t_{m}\left({ }^{\circ} \mathrm{C}\right)$, in Figure 6. Each curve in Figure 6 presents two or three peaks. These peaks correspond to decomposition of hemicellulose, cellulose, and lignin [31-39]. Hemicellulose and cellulose decompose at temperature ranges of $150-360{ }^{\circ} \mathrm{C}$ and $240-400{ }^{\circ} \mathrm{C}$, respectively, whereas lignin decomposes within a broad temperature range of $160-900{ }^{\circ} \mathrm{C}[32,37]$. Decomposition temperature range, peak height (i.e., maximum decomposition rate), and temperature corresponding to the maximum decomposition rate, $t_{m, \max }$, depend on the content of hemicellulose, cellulose, and lignin of vegetal material. Vine prunings contain $31-34 \mathrm{wt} \%$ hemicellulose, $37-40 \mathrm{wt} \%$ cellulose, and 27-30 wt\% lignin [40]. The first 2 peaks in Figure 6, corresponding to lower decomposition temperatures of $123-312{ }^{\circ} \mathrm{C}\left(t_{m, \max }=182-245^{\circ} \mathrm{C}\right)$ and $209-412{ }^{\circ} \mathrm{C}\left(t_{m, \max }=298-338{ }^{\circ} \mathrm{C}\right)$, respectively, could be associated with the decomposition of hemicellulose and a part of lignin, whereas the last peak, corresponding to a decomposition temperature range of $225-487^{\circ} \mathrm{C}\left(t_{m, \max }=355-438^{\circ} \mathrm{C}\right)$, could be associated with the decomposition of cellulose and remaining lignin $[32,34,35]$.

$$
\alpha=\frac{m_{0}-m}{m_{0}-m_{f}}
$$
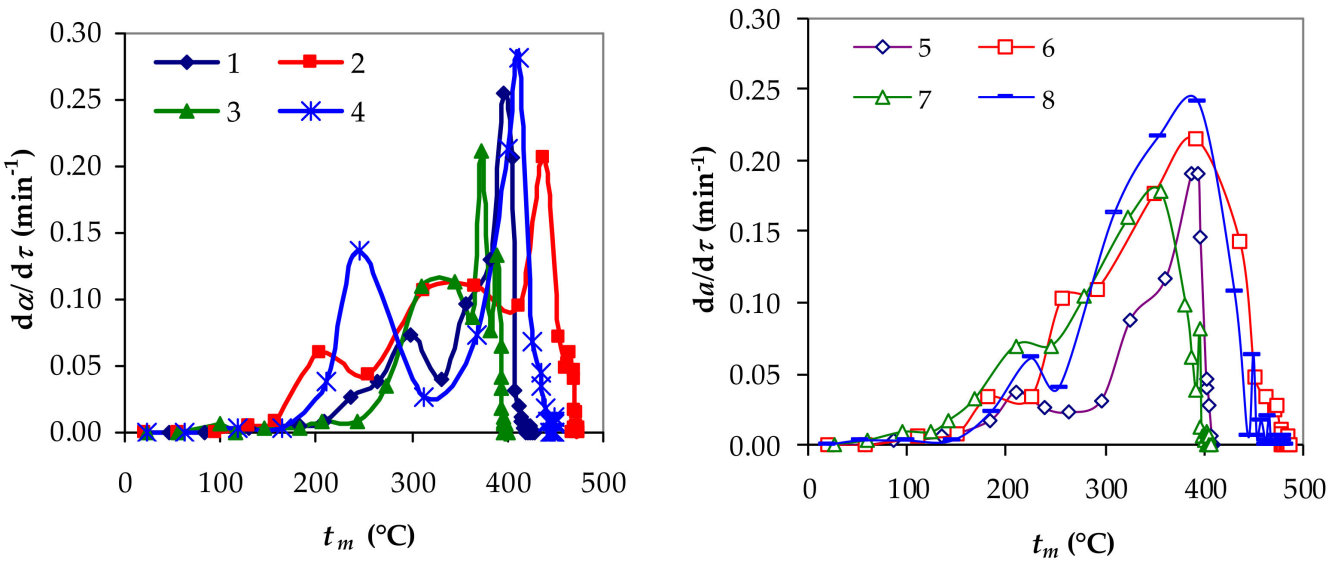

Figure 6. Decomposition rate of vine waste vs. mean temperature of fixed bed.

\subsection{Predicted Performances of Slow Pyrolysis}

Pyrolysis performances were predicted depending on dimensionless process factors using multiple regression equations based on a $2^{3}$ factorial design. Dimensionless factors $\left(x_{j}, j=1 . .3\right)$ are given by Equations (9)-(11), where $q_{c p}=5010 \mathrm{~W} / \mathrm{m}^{2}, w_{c p}=0.006 \mathrm{~m} / \mathrm{s}$, and 
$d_{c p}=0.009 \mathrm{~m}$ are centre-points. In order to test the significance of regression coefficients, three centre-point runs (9-12 in Table 2) were conducted. The effects of $x_{j}(j=1 . .3)$ and factor interactions $\left(x_{1} x_{2}, x_{1} x_{3}, x_{2} x_{3}\right.$, and $\left.x_{1} x_{2} x_{3}\right)$ on $y_{i}(i=1 . .3)$ were quantified using statistical models described by Equations (12)-(14), where $y_{1}=\left(m_{f} / m_{0}\right)_{\text {calc }}, y_{2}=\left(m_{L f} / m_{0}\right)_{\text {calc }}$, and $y_{3}=t_{m f \text { rcalc }}$ are process performances and $\beta_{k i}(k=1 . .8, i=1 . .3)$ regression coefficients. Regression coefficients, which were determined based on experimental data summarized in Table 1, are given in Supplementary Tables S1-S3 along with values of standard errors $\left(S E_{k i}\right)$, $t$ statistics $\left(t_{k i}\right), p$-values $\left(p_{k i}\right)$, multiple determination coefficient $\left(R^{2}\right)$, adjusted $R^{2}\left(R^{2}\right.$ adj $)$, regression standard error $(R S E), F$ statistic $(F)$, and significance $F$ ( $p$-value for $F$ ). Statistically significant coefficients ( $p_{k i} \leq \alpha=0.05$, where $\alpha$ is the significance level) in Supplementary Tables S1-S3 are written in bold. Tabulated results indicate that Equations (12)-(14) fit the data very well $\left(R^{2} \geq 0.979, R_{\text {adj }}^{2} \geq 0.930, R S E \leq 23.62, F \geq 20.08, p \leq 0.016\right)$. According to Equations (12)-(14), lower levels of $\mathrm{CO}_{2}$ superficial velocity $\left(x_{2}\right)$ and higher levels of particle size $\left(x_{3}\right)$ lead to higher values of mean bed temperature $\left(y_{3}\right)$ and bio-oil yield $\left(y_{2}\right)$ as well as to lower values of biochar yield $\left(y_{1}\right)$. Moreover, data summarized in Supplementary Tables S1-S3 indicate significant negative effects of $x_{1} x_{2}, x_{1} x_{3}$, and $x_{1} x_{2} x_{3}$ on $y_{2}$ and significant positive effects of $x_{1} x_{3}$ and $x_{2} x_{3}$ on $y_{3}$. After removing statistically non-significant terms in Equations (12)-(14), only Equation (15) fits the data very well, i.e., $R^{2}=0.894$, $R^{2}{ }_{a d j}=0.868, R S E=0.004, F=33.83, p=1.2 \mathrm{E}-04$ (Supplementary Table S4). Accordingly, Equations (13)-(15) can be used to predict the pyrolysis performances for values of process factors within ranges considered in the experimental study.

$$
\begin{aligned}
& x_{1}=\frac{q-5010}{766} \\
& x_{2}=\frac{w-0.006}{0.002} \\
& x_{3}=\frac{d-0.009}{0.002}
\end{aligned}
$$

$$
\begin{gathered}
y_{1}=0.3095+0.0093 x_{2}-0.0078 x_{3}+0.0013 x_{1} x_{2}-0.0008 x_{1} x_{3}+0.0008 x_{2} x_{3}+0.0008 x_{1} x_{2} x_{3} \\
y_{2}=0.3111-0.0018 x_{2}+0.0082 x_{3}-0.0052 x_{1} x_{2}-0.0133 x_{1} x_{3}-0.0018 x_{2} x_{3}-0.0143 x_{1} x_{2} x_{3} \\
y_{3}=441.4-7.2218 x_{2}+3.5258 x_{3}-0.7164 x_{1} x_{2}+7.1628 x_{1} x_{3}+5.2413 x_{2} x_{3}-0.9845 x_{1} x_{2} x_{3} \\
y_{1}=0.3095+0.0093 x_{2}-0.0078 x_{3}
\end{gathered}
$$

Table 2. Physicochemical properties of biochar.

\begin{tabular}{cc}
\hline Proximate Analysis (\% wb) & \\
\hline Dry Matter Content, DM & $98.14 \pm 0.51$ \\
Volatile Matter Content, VM & $32.29 \pm 1.60$ \\
Ash Content, Ash & $7.90 \pm 0.59$ \\
Fixed Carbon Content, FC & $57.96 \pm 1.25$ \\
\hline Ultimate Analysis (\% dafb) \\
\hline$C$ & $69.37 \pm 0.22$ \\
$H$ & $3.59 \pm 0.05$ \\
$S$ & $2.33 \pm 0.04$ \\
$O$ & 0 \\
Bulk Density, BD (g/cm $\left.{ }^{3}\right)$ & $24.71 \pm 1.43$ \\
Electrical Conductivity, $E C(\mathrm{dS} / \mathrm{m})$ & $0.112 \pm 0.001$ \\
WH & $0.55 \pm 0.03$ \\
Water Holding Capacity, $W H C(\%)$ & $10.35 \pm 0.06$ \\
\hline
\end{tabular}




\subsection{Biochar and Bio-Oil Characterization}

Pyrolysis products resulting from exp. $6\left(q=5777 \mathrm{~W} / \mathrm{m}^{2}, w=0.004 \mathrm{~m} / \mathrm{s}, d=0.011 \mathrm{~m}\right)$, where the highest bio-oil yield (0.350) and the lowest biochar yield (0.286) were obtained, were analyzed physicochemically.

\subsubsection{Biochar Characterization}

Pyrolysis biochar kept the form and dimensions of initial chopped vine waste (Figure 7).

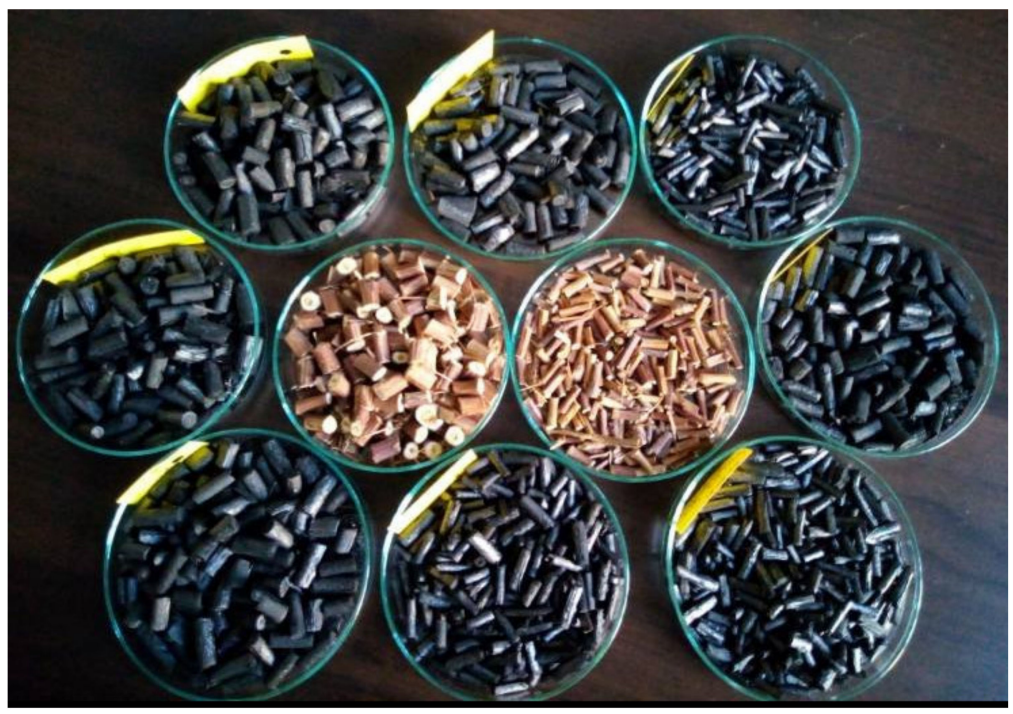

Figure 7. Biochar obtained (exp. 1-8 in Table 1) from coarse and fine chopped vine prunings.

The results of physicochemical analyses of biochar obtained, which are summarized in Table 2, are in accordance with those reported in the related literature [18,41-44]. Tabulated data indicate high level of $C(69.37 \pm 0.22 \%)$, low level of $O(24.71 \pm 1.43 \%)$ as well as very low values of $H(3.59 \pm 0.05 \%)$ and $N(2.33 \pm 0.04 \%)$. Low values of $B D$ $\left(0.112 \pm 0.001 \mathrm{~g} / \mathrm{cm}^{3}\right)$ and $E C(0.55 \pm 0.03 \mathrm{dS} / \mathrm{m})$ as well as relatively high level of WHC $(58.99 \pm 14.51 \%)$ of biochar make it suitable to be used as soil amendment. Moreover, due to its high $p H(10.35 \pm 0.06)$, it is recommended for acidic soils.

SEM micrographs of vine waste and its biochar (Figure 8) show significant morphological changes after pyrolysis. The void volume of the biochar is significantly higher than that of its precursor. Accordingly, the thermo-chemical treatment improves the porous structure of biochar due to the removal of a part of volatile matter from the starting vegetal material [41]. The loss of water and organic fragments during the pyrolysis led to a decrease in the mass of vegetal material (by $71.4 \%$ for exp. 6) and an improvement in the porous structure. The biochar with developed porosity can be applied as an adsorbent for environmental remediation. 


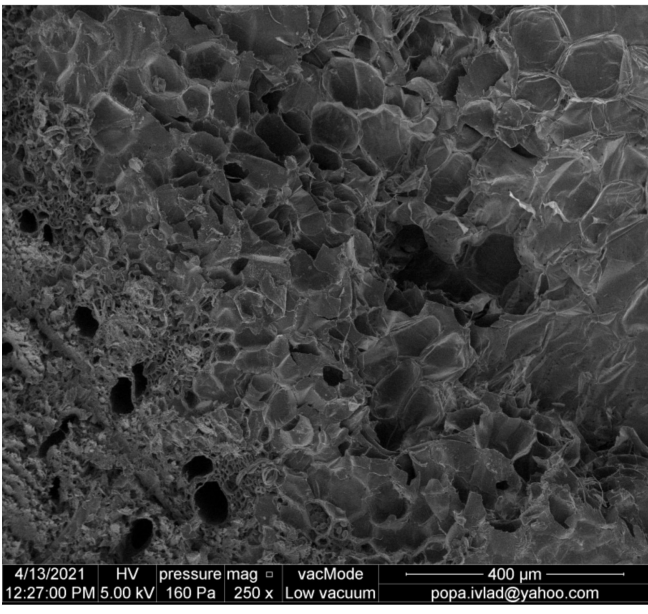

(a)

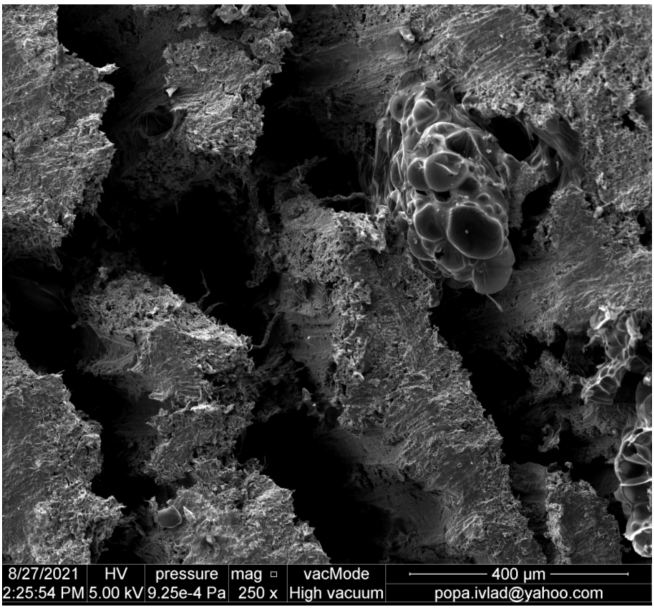

(b)

Figure 8. Scanning electron microscope (SEM) images of: (a) vine waste; (b) vine waste biochar.

The FT-IR spectrum of vine waste biochar (Figure 9) shows four relevant peaks, i.e.,: (i) a first peak at $3199 \mathrm{~cm}^{-1}$ ascribed to $\mathrm{O}-\mathrm{H}$ stretching vibration of hydroxyl groups attached to aromatic rings [41,42]; (ii) a second peak at $1579 \mathrm{~cm}^{-1}$ corresponding to $C=C$ stretching in the aromatic ring [45]; (iii) a third peak at $1314 \mathrm{~cm}^{-1}$ assigned to aromatic C-O stretching [45]; (iv) a last peak at $756 \mathrm{~cm}^{-1}$ attributed to aromatic C-H bending vibrations (two adjacent $\mathrm{H}$ out-of-plane deformations) [41,44-46]. FT-IR spectrum suggests the presence of various aromatic hydrocarbons and some functional groups containing oxygen.

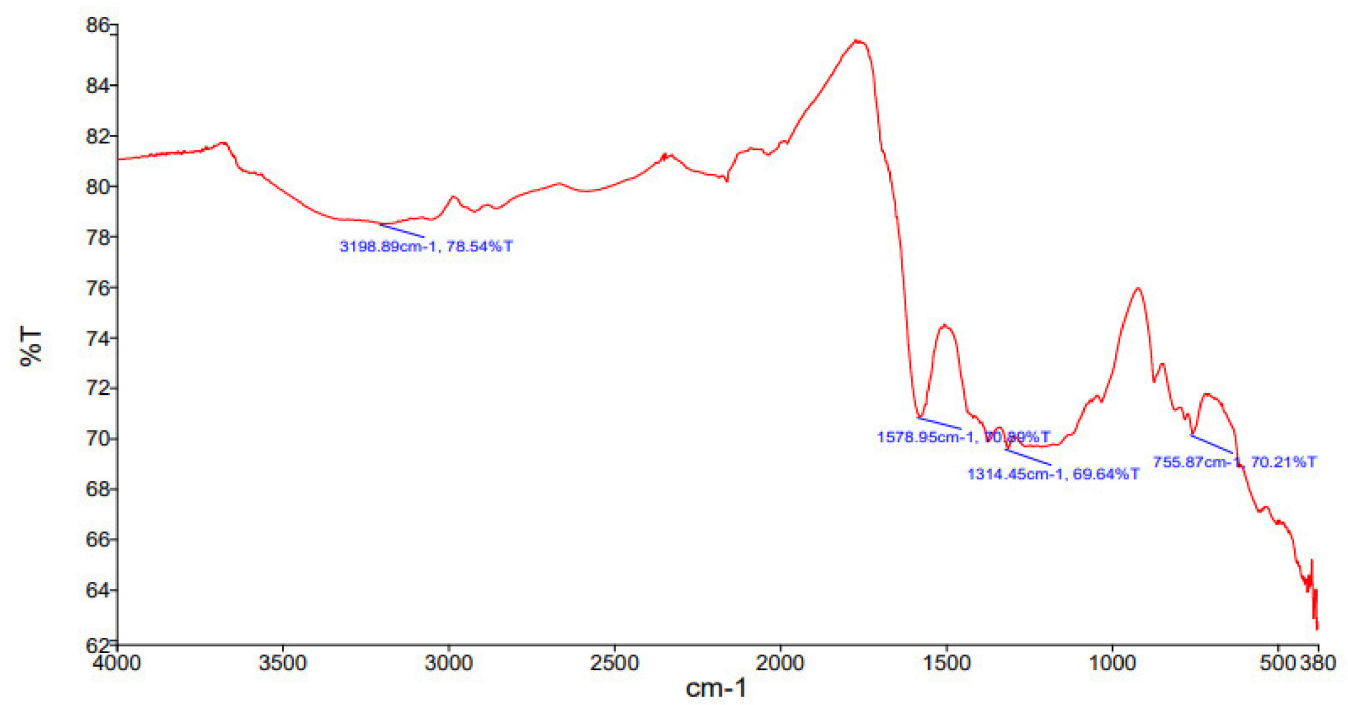

Figure 9. Fourier transform infrared (FT-IR) spectrum of vine waste biochar.

\subsubsection{Bio-Oil Characterization}

The results of physicochemical analyses of bio-oil obtained in exp. 6 (Figure 10), which are summarized in Table 3, are in a reasonable agreement with those reported in the related literature [47-50]. Values of density $(\rho)\left(1.027 \pm 0.014 \mathrm{~g} / \mathrm{cm}^{3}\right)$ are higher and of $p H$ $(3.34 \pm 0.02)$ are lower than those of diesel fuel $\left(0.82-0.85 \mathrm{~g} / \mathrm{cm}^{3}\right.$ and $5.5-8$, respectively). Low $\mathrm{pH}$ values indicate a high acidity of pyrolytic bio-oil, which is the major reason that limits its direct use as a transport fuel [49]. Moreover, values of water content $(W)$ are high, i.e., $33.2 \pm 1.27 \%$. Higher levels of $W$ decrease the $p H$ and heating value of bio-oil and can enhance phase separation, resulting in an organic phase and an aqueous one [51]. These phases can be subsequently separated, e.g., by centrifugation [47]. 


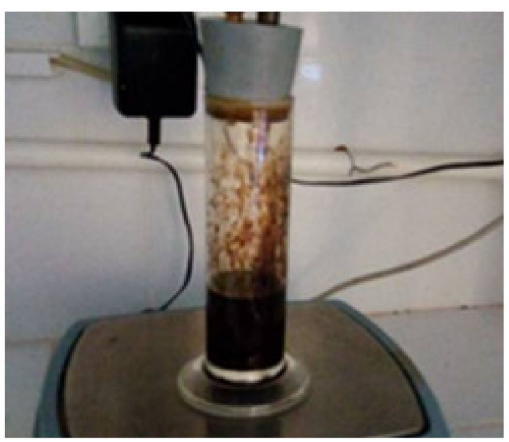

Figure 10. Pyrolysis liquid (bio-oil).

Table 3. Physicochemical properties of bio-oil.

\begin{tabular}{cc}
\hline Parameter (Units) & Mean Value \pm SD \\
\hline Water Content, $W(\%)$ & $33.2 \pm 1.27$ \\
Density, $\rho\left(\mathrm{g} / \mathrm{cm}^{3}\right)$ & $1.027 \pm 0.014$ \\
$p H$ & $3.34 \pm 0.02$ \\
Refractive Index, $R I$ & $1.3553 \pm 0.0027$ \\
Iodine Value, $I V\left(\mathrm{~g} \mathrm{I}_{2} / 100 \mathrm{~g}\right.$ Bio-Oil $)$ & $87.98 \pm 4.38$ \\
\hline
\end{tabular}

The results of GC-MS analysis, which are presented in Figure 11 and Table 4, highlight that bio-oil produced from vine pruning waste is a mixture of various organic compounds, including phenols, carboxylic acids, ketones, aldehydes, alcohols, esters, ethers, furans, and nitrogen-containing heterocyclic compounds. Chemical compounds of the bio-oil were similar to those reported by other researchers [50,52]. Depending on the peak area $(A)$, the most abundant compounds were 2,6-dimethoxyphenol (syringol) $(A=13.25 \%)$, phenol $(A=10.75 \%)$, 3-furaldehyde $(A=10.71 \%), 4$-hydroxybutanoic acid ( $\gamma$-hydroxybutyric acid) ( $A=7.90 \%)$, 2-methoxyphenol (guaiacol) $(A=6.74 \%)$, and 3-methyl-1,2- cyclopentanedione $(A=5.49 \%)$. Phenol and its derivatives are widely used in the production of phenolic resins, phenoxy herbicides, detergents, pharmaceuticals, medicinal preparations, nylon and other synthetic fibers [52]. Syringol and guaiacol, compounds obtained by lignin pyrolysis, are used in preparation of food by smoking [52]. Moreover, guaiacol is a precursor of flavorants (e.g., eugenol, vanillin) as well as it is used as an antiseptic, local anesthetic, and expectorant. 3-Furaldehyde (furan-3-carbaldehyde) is a solvent and a precursor of thiosemicarbazones [53]. $\gamma$-Hydroxybutyric acid (GHB) is effective for the treatment of narcolepsy and alcohol dependence [54]. Antioxidant and anti-inflammatory effects of 3methyl-1,2-cyclopentanedione were reported in the related studies [55,56]. Accordingly, biooil produced by slow pyrolysis of vine prunings is a valuable source of various chemicals. Data summarized in Table 4 indicate a high oxygen content of pyrolysis bio-oil. It is possible to upgrade the bio-oil for future use as a fossil fuel substitute. 


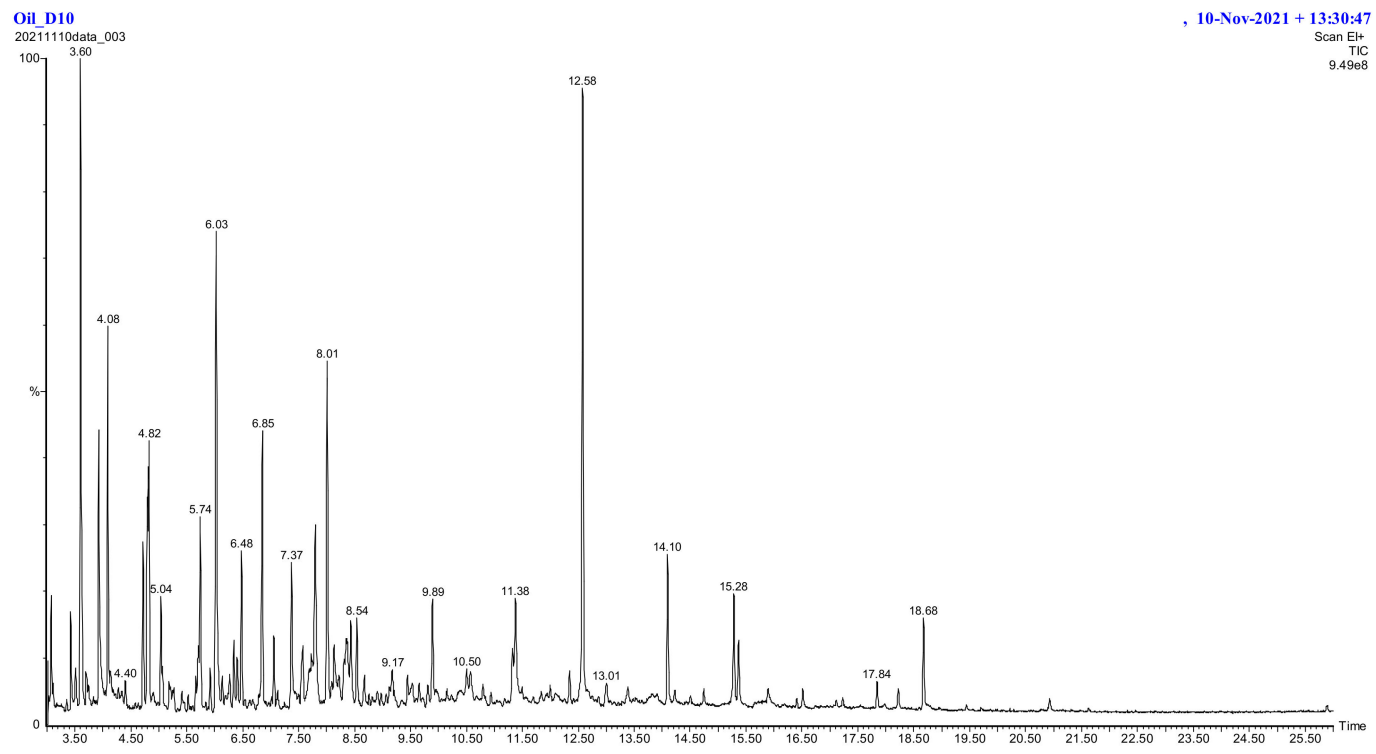

Figure 11. Gas chromatography mass spectrometry (GC-MS) total ion chromatogram of bio-oil.

Table 4. Chemical composition of bio-oil.

\begin{tabular}{|c|c|c|c|c|c|}
\hline No. & Chemical Compound & $\begin{array}{l}\text { Molecular } \\
\text { Formula }\end{array}$ & $\begin{array}{c}\text { CAS } \\
\text { Number }\end{array}$ & $\begin{array}{c}\text { Retention Time } \\
\tau_{R}(\mathrm{~min})\end{array}$ & $\begin{array}{c}\text { Peak Area } \\
\quad A(\%)\end{array}$ \\
\hline 1 & Cyclopentanone & $\mathrm{C}_{5} \mathrm{H}_{8} \mathrm{O}$ & $120-92-3$ & 3.07 & 1.19 \\
\hline 2 & 2-Methylpyridine & $\mathrm{C}_{6} \mathrm{H}_{7} \mathrm{~N}$ & $109-06-8$ & 3.43 & 1.26 \\
\hline 3 & 3-Furaldehyde & $\mathrm{C}_{5} \mathrm{H}_{4} \mathrm{O}_{2}$ & $498-60-2$ & 3.6 & 10.71 \\
\hline 4 & 2-Furanmethanol & $\mathrm{C}_{5} \mathrm{H}_{6} \mathrm{O}_{2}$ & $98-00-0$ & 3.93 & 4.56 \\
\hline 5 & 1-(Acetyloxy)-2-propanone & $\mathrm{C}_{5} \mathrm{H}_{8} \mathrm{O}_{3}$ & $592-20-1$ & 4.08 & 4.14 \\
\hline 6 & 2-Methyl-2-cyclopenten-1-one & $\mathrm{C}_{6} \mathrm{H}_{8} \mathrm{O}$ & $1120-73-6$ & 4.72 & 2.91 \\
\hline 7 & 4-Hydroxybutanoic acid & $\mathrm{C}_{4} \mathrm{H}_{8} \mathrm{O}_{3}$ & $591-81-1$ & 4.82 & 7.90 \\
\hline 8 & 1,2-Cyclopentanedione & $\mathrm{C}_{5} \mathrm{H}_{6} \mathrm{O}_{2}$ & $3008-40-0$ & 5.04 & 2.30 \\
\hline 9 & 3-Methyl-2-cyclopenten-1-one & $\mathrm{C}_{6} \mathrm{H}_{8} \mathrm{O}$ & 2758-18-1 & 5.74 & 4.05 \\
\hline 10 & Phenol & $\mathrm{C}_{6} \mathrm{H}_{6} \mathrm{O}$ & $108-95-2$ & 6.03 & 10.75 \\
\hline 11 & Tetrahydrofuran-2-carbonyl chloride & $\mathrm{C}_{5} \mathrm{H}_{7} \mathrm{ClO}_{2}$ & $52449-98-6$ & 6.48 & 2.56 \\
\hline 12 & 3-Methyl-1,2-cyclopentanedione & $\mathrm{C}_{6} \mathrm{H}_{8} \mathrm{O}_{2}$ & $765-70-8$ & 6.85 & 5.49 \\
\hline 13 & 2,3-Dimethyl-2-cyclopenten-1-one & $\mathrm{C}_{7} \mathrm{H}_{10} \mathrm{O}$ & $1121-05-7$ & 7.06 & 1.42 \\
\hline 14 & 2-Methylphenol & $\mathrm{C}_{7} \mathrm{H}_{8} \mathrm{O}$ & $95-48-7$ & 7.37 & 3.05 \\
\hline 15 & 3-Methylphenol & $\mathrm{C}_{7} \mathrm{H}_{8} \mathrm{O}$ & $108-39-4$ & 7.79 & 4.09 \\
\hline 16 & 2-Methoxyphenol (guaiacol) & $\mathrm{C}_{7} \mathrm{H}_{8} \mathrm{O}_{2}$ & $90-05-1$ & 8.01 & 6.74 \\
\hline 17 & 3-Ethyl-2-hydroxy-2-cyclopenten-1-one & $\mathrm{C}_{7} \mathrm{H}_{10} \mathrm{O}_{2}$ & 21835-01-8 & 8.54 & 1.60 \\
\hline 18 & Creosol & $\mathrm{C}_{8} \mathrm{H}_{10} \mathrm{O}_{2}$ & $93-51-6$ & 9.89 & 1.95 \\
\hline 19 & 4-Ethyl-2-methoxyphenol & $\mathrm{C}_{9} \mathrm{H}_{12} \mathrm{O}_{2}$ & $2785-89-9$ & 11.38 & 1.55 \\
\hline 20 & 2,6-Dimethoxyphenol (syringol) & $\mathrm{C}_{8} \mathrm{H}_{10} \mathrm{O}_{3}$ & $91-10-1$ & 12.58 & 13.25 \\
\hline 21 & 3,5-Dimethoxy-4-hydroxytoluene & $\mathrm{C}_{9} \mathrm{H}_{12} \mathrm{O}_{3}$ & $6638-05-7$ & 14.1 & 2.85 \\
\hline 22 & 1,2,3-Trimethoxy-5-methylbenzene & $\mathrm{C}_{10} \mathrm{H}_{14} \mathrm{O}_{3}$ & $6443-69-2$ & 15.28 & 2.24 \\
\hline 23 & $\begin{array}{c}\text { 1-(4-Hydroxy-3,5- } \\
\text { dimethoxyphenyl)ethanone }\end{array}$ & $\mathrm{C}_{10} \mathrm{H}_{12} \mathrm{O}_{4}$ & $2478-38-8$ & 18.22 & 0.54 \\
\hline 24 & Syringylacetone & $\mathrm{C}_{11} \mathrm{H}_{14} \mathrm{O}_{4}$ & $19037-58-2$ & 18.68 & 2.09 \\
\hline 25 & $\begin{array}{l}\text { 1-(4-Hydroxy-3,5-dimethoxyphenyl)-1- } \\
\text { propanone }\end{array}$ & $\mathrm{C}_{11} \mathrm{H}_{14} \mathrm{O}_{4}$ & $5650-43-1$ & 19.44 & 0.18 \\
\hline 26 & $\begin{array}{c}\text { 5,10-Diethoxy-2,3,7,8-tetrahydro- } 1 \mathrm{H}, 6 \mathrm{H} \text { - } \\
\text { dipyrrolo } \\
{\left[1,2-\mathrm{a}: 1^{\prime}, 2^{\prime} \text {-d]pyrazine }\right.}\end{array}$ & $\mathrm{C}_{14} \mathrm{H}_{22} \mathrm{~N}_{2} \mathrm{O}_{2}$ & - & 20.93 & 0.44 \\
\hline 27 & Hexanedioic acid dioctyl ester & $\mathrm{C}_{22} \mathrm{H}_{42} \mathrm{O}_{4}$ & $123-79-5$ & 25.9 & 0.18 \\
\hline
\end{tabular}




\section{Conclusions}

Slow pyrolysis of vine pruning waste was performed for $60 \mathrm{~min}$ in a fixed bed reactor, in the presence of $\mathrm{CO}_{2}$ as a carrier gas and oxidizing agent. Biochar, bio-oil, and pyrolysis gases were produced under different operating conditions, according to a $2^{3}$ factorial design.

Process factors were heat flux $\left(4244-5777 \mathrm{~W} / \mathrm{m}^{2}\right), \mathrm{CO}_{2}$ superficial velocity $(0.004-$ $0.008 \mathrm{~m} / \mathrm{s})$, and mean size of vegetal material $(0.007-0.011 \mathrm{~m})$. Specific masses of vine waste and bio-oil, defined as product mass divided by initial mass of vegetal waste, and mean bed temperature were selected as process responses. Final yields of biochar and bio-oil were of $0.286-0.328$ and $0.260-0.350$, respectively, whereas final values of mean bed temperature were of $401.1-486.5{ }^{\circ} \mathrm{C}$. It was found that the pyrolysis process developed intensely in two or three stages, corresponding to decomposition of cellulose, hemicellulose, and lignin.

Final values of process responses were predicted depending on dimensionless factors using multiple regression equations. Under conditions studied, the effects of heat flux $\left(x_{1}\right)$, carrier gas superficial velocity $\left(x_{2}\right)$, and vegetal material particle size $\left(x_{3}\right)$ on final process performances were as follows: (i) $x_{2}$ had a significant positive effect and $x_{3}$ a significant negative effect on biochar yield; (ii) $x_{3}$ had a significant positive effect, whereas $x_{1} x_{2}, x_{1} x_{3}$, and $x_{1} x_{2} x_{3}$ had significant negative effects on bio-oil yield; (iii) $x_{2}$ had a significant negative effect, $x_{3}$ a significant positive effect, whereas $x_{1} x_{3}$ and $x_{2} x_{3}$ had significant positive effects on mean bed temperature.

The biochar and bio-oil were characterized using specific analytical methods. Due to its low values of bulk density $\left(0.112 \pm 0.001 \mathrm{~g} / \mathrm{cm}^{3}\right)$ and electrical conductivity $(0.55 \pm 0.03 \mathrm{dS} / \mathrm{m})$ as well as to high levels of $p H(10.35 \pm 0.06)$ and water holding capacity $(58.99 \pm 14.51 \%)$, the biochar could be used as soil amendment for acidic soils. Moreover, its structure can be modified by impregnation and/or activation, obtaining engineered biochar for specific applications, e.g., environmental remediation. Twenty-seven possible organic compounds (phenols, carboxylic acids, ketones, aldehydes, alcohols, esters, ethers, furans, and nitrogencontaining heterocyclic compounds) were identified in bio-oil by GC-MS analysis, the most abundant being syringol, phenol, 3-furaldehyde, 4-hydroxybutanoic acid, guaiacol, and 3-methyl-1,2-cyclopentanedione. The bio-oil represents a valuable source of chemicals and it can also be mixed with diesel or gasoline after a previous upgrade.

Supplementary Materials: The following are available online at https:/ /www.mdpi.com/article/10 .3390/pr10010037/s1, Table S1: Results of multiple regression analysis for $y_{1}$ expressed by Equation (12), Table S2: Results of multiple regression analysis for $y_{2}$ expressed by Equation (13), Table S3: Results of multiple regression analysis for $y_{3}$ expressed by Equation (14), Table S4: Results of multiple regression analysis for $y_{1}$ expressed by Equation (15).

Author Contributions: Conceptualization, S.I.C., O.C.P. and V.A.I.; methodology, S.I.C., O.C.P., V.A.I., C.E.R., A.M., V.P. and M.E.C.; validation, O.C.P. and V.A.I.; formal analysis, O.C.P.; investigation, S.I.C., V.A.I., C.E.R., A.M., V.P. and M.E.C.; writing—original draft preparation, S.I.C., O.C.P., V.A.I. and D.E.; writing-review and editing, O.C.P. and V.A.I.; supervision, L.B. and T.D. All authors have read and agreed to the published version of the manuscript.

Funding: This work was supported by a grant of the Romanian Ministry of Education and Research, CCCDI - UEFISCDI, project number 372PED/2020 (PN-III-P2-2.1-PED-2019-4917), within PNCDI III.

Data Availability Statement: Not applicable.

Conflicts of Interest: The authors declare no conflict of interest. 


\section{References}

1. Chen, X.; Che, Q.; Li, S.; Liu, Z.; Yang, H.; Chen, Y.; Wang, X.; Shao, J.; Chen, H. Recent developments in lignocellulosic biomass catalytic fast pyrolysis: Strategies for the optimization of bio-oil quality and yield. Fuel Process. Technol. 2019, 196, 106180. [CrossRef]

2. El Hanandeh, A.; Albalasmeh, A.; Gharaibeh, M. Effect of pyrolysis temperature and biomass particle size on the heating value of biocoal and optimization using surface methodology. Biomass Bioenerg. 2021, 151, 106163. [CrossRef]

3. Ghosh, P.; Sengupta, S.; Singh, L.; Sahay, A. Life cycle assessment of waste-to-bionergy processes: A review. In Bioreactors; Singh, L., Yousuf, A., Mahapatra, D.M., Eds.; Elsevier: Amsterdam, The Netherlands, 2020; pp. 105-122. ISBN 9780128212646. [CrossRef]

4. Kimura, L.M.; Santos, L.C.; Vieira, P.F.; Parreira, P.M.; Henrique, H.M. Biomass pyrolysis: Use of some agricultural wastes for alternative fuel production. In Proceedings of the 7th International Latin American Conference on Powder Technology, Atibaia, Brazil, 8-10 November 2009; pp. 274-279.

5. Tian, B.; Wang, X.; Zhao, W.; Xu, L.; Bai, L. Pyrolysis behaviors, kinetics and gaseous product evolutions of two typical biomass wastes. Catal. Today 2021, 374, 77-85. [CrossRef]

6. Wang, G.; Dai, G.; Ding, S.; Wu, J.; Wang, S. A new insight into pyrolysis mechanism of three typical actual biomass: The influence of structural differences on pyrolysis process. J. Anal. Appl. Pyrolysis 2021, 156, 105184. [CrossRef]

7. Ansari, K.B.; Kamal, B.; Beg, S.; Khan, M.A.W.; Khan, M.S.; Al Mesfer, M.K.; Danish, M. Recent developments in investigating reactions chemistry and transport effects in biomass fast pyrolysis: A review. Renew. Sust. Energ. Rev. 2021, 150, 111454. [CrossRef]

8. Cusenza, M.A.; Longo, S.; Cellura, M.; Guarino, F.; Messineo, A.; Mistretta, M.; Volpe, M. Environmental assessment of a waste-to-bioenergy practice: The pyrolysis of agro-industrial biomass residues. Sustain. Prod. Consum. 2021, 28, 866-876. [CrossRef]

9. Li, Y.; Xing, B.; Ding, Y.; Han, X.; Wang, S. A critical review of the production and advanced utilization of biochar via selective pyrolysis of lignocellulosic biomass. Bioresour. Technol. 2020, 312, 123614. [CrossRef]

10. Mlonka-Medrala, A.; Evangelopoulos, P.; Sieradzka, M.; Zajemska, M.; Magdziarz, A. Pyrolysis of agricultural waste biomass towards production of gas fuel and high-quality char: Experimental and numerical investigations. Fuel 2021, $296,120611$. [CrossRef]

11. Tang, Q.; Chen, Y.; Yang, H.; Liu, M.; Xiao, H.; Wang, S.; Chen, H.; Naqvi, S.R. Machine learning prediction if pyrolytic gas yield and compositions with feature reduction methods: Effect of pyrolysis conditions and biomass characteristics. Bioresour. Technol. 2021, 339, 125581. [CrossRef]

12. Usino, D.O.; Ylitervo, P.; Moreno, A.; Sipponen, M.H. Primary interactions of biomass components during fast pyrolysis. J. Anal Appl. Pyrolysis 2021, 159, 105297. [CrossRef]

13. Pârvulescu, O.C.; Gavrilă, A.I.; Dobre, T.; Ceatră, L. Effects of process factors on slow pyrolysis of sorghum waste. Rev. Chim. 2016, 67, 2254-2257.

14. Dobre, T.; Pârvulescu, O.C.; Iavorschi, G.; Stoica, A.; Stroescu, M. Catalytic effects at pyrolysis of wheat grains impregnated with nickel salts. Int. J. Chem. React. Eng. 2010, 8, 1968-1992. [CrossRef]

15. Dobre, T.; Pârvulescu, O.C.; Rodriguez Ramos, I.; Ceatră, L.; Stroescu, M.; Stoica, A.; Mirea, R. Global reaction kinetics and enthalpy in slow pyrolysis of vegetal materials. Rev. Chim. 2012, 63, 54-59.

16. Pârvulescu, O.C.; Dobre, T.; Ceatră, L.; Iavorschi, G.; Mirea, R. Characteristics of corn grains pyrolysis in a fixed bed reactor. Rev. Chim. 2011, 62, 89-94.

17. Balat, M.; Balat, M.; Kirtay, E.; Balat, H. Main routes for the thermo-conversion of biomass into fuels and chemicals. Part 1: Pyrolysis systems. Energ. Convers. Manag. 2009, 50, 3147-3157. [CrossRef]

18. Tomczyk, A.; Sokołowska, Z.; Boguta, P. Biochar physicochemical properties: Pyrolysis temperature and feedstock kind effects. Rev. Environ. Sci. Biotechnol. 2020, 19, 191-215. [CrossRef]

19. Di Blasi, C. Modelling chemical and physical processes of wood and biomass pyrolysis. Prog. Energy Combust. Sci. 2008, 34, 47-90. [CrossRef]

20. Chen, W.; Meng, J.; Han, X.; Lan, Y.; Zhang, W. Past, present, and future of biochar. Biochar 2019, 1, 75-87. [CrossRef]

21. Gonzalez, J.F.; Encinar, J.M.; Canito, J.L.; Sabio, E.; Chacon, M. Pyrolysis of cherry stones: Energy uses of the different fractions and kinetic study. J. Anal. Appl. Pyrolysis 2003, 67, 165-190. [CrossRef]

22. Janu, R.; Mrlik, V.; Ribitsch, D.; Hofman, J.; Sedláček, P.; Bielska, L.; Soja, G. Biochar surface functional groups as affected by biomass feedstock, biochar composition and pyrolysis temperature. Carbon Resour. Convers. 2021, 4, 36-46. [CrossRef]

23. Khan, M.B.; Cui, X.; Jilani, G.; Tang, L.; Lu, M.; Cao, X.; Sahito, Z.A.; Hamid, Y.; Hussain, B.; Yang, X.; et al. New insight into the impact of biochar during vermi-stabilization of divergent biowastes: Literature synthesis and research pursuits. Chemosphere 2000, 238, 124679. [CrossRef]

24. Purakayastha, T.J.; Bera, T.; Bhaduri, D.; Sarkar, B.; Mandal, S.; Wade, P.; Kumari, S.; Biswas, S.; Menon, M.; Pathak, H.; et al. A review on biochar modulated soil condition improvements and nutrient dynamics concerning crop yields: Pathways to climate change mitigation and global food security. Chemosphere 2019, 227, 345-365. [CrossRef]

25. Ceatră, L.; Pârvulescu, O.C.; Rodriguez Ramos, I.; Dobre, T. Preparation, characterization, and testing of a carbon-supported catalyst obtained by slow pyrolysis of nickel salt impregnated vegetal material. Ind. Eng. Chem. Res. 2016, 55, 1491-1502. [CrossRef] 
26. Qian, K.; Kumar, A.; Zhang, H.; Bellmer, D.; Huhnke, R. Recent advances in utilization of biochar. Renew. Sustain. Energy Rev. 2015, 42, 1055-1064. [CrossRef]

27. Yorgun, S.; Şensöz, S.; Koçkar, Ö.M. Characterization of the pyrolysis oil produced in the slow pyrolysis of sunflower-extracted bagasse. Biomass Bioenerg. 2001, 20, 141-148. [CrossRef]

28. Al Jamri, M.; Li, J.; Smith, R. Molecular characterisation of biomass pyrolysis oil and petroleum fraction blends. Comput. Chem. Eng. 2020, 140, 106906. [CrossRef]

29. ASTM D5142. Standard Test Methods for Proximate Analysis of the Analysis Sample of Coal and Coke by Instrumental Procedures; ASTM International: West Conshohocken, PA, USA, 2009.

30. Bikbulatova, S.; Tahmasebi, A.; Zhang, Z.; Rish, S.K.; Yu, J. Understanding water retention behavior and mechanism in bio-char. Fuel Process. Technol. 2018, 169, 101-111. [CrossRef]

31. Antal, M.J.J.; Varhegyi, G. Cellulose pyrolysis kinetics: The current state of knowledge? Ind. Eng. Chem. Res. 1995, 34, 703-717. [CrossRef]

32. Babiker, M.E.; Aziz, A.R.A.; Heilkal, M.; Yusup, S.; Abakar, M. Pyrolysis characteristics of Phoenix dactylifera date palm seeds using thermo-gravimetric analysis (TGA). Int. J. Environ. Sci. Dev. 2013, 4, 521-524. [CrossRef]

33. Damartzis, T.; Vamvuka, D.; Sfakiotakis, S.; Zabaniotou, A. Thermal degradation studies and kinetic modeling of cardoon (Cynara cardunculus) pyrolysis using thermogravimetric analysis (TGA). Bioresour. Technol. 2011, 102, 6230-6238. [CrossRef]

34. El-Sayed, S.A.; Mostafa, M.E. Kinetic parameters determination of biomass pyrolysis fuels using TGA and DTA techniques. Waste Biomass Valor. 2015, 6, 401-415. [CrossRef]

35. El-Sayed, S.A.; Mostafa, M.E. Pyrolysis characteristics and kinetic parameters determination of biomass fuel powders by differential thermal gravimetric analysis (TGA/DTG). Energy Convers. Manag. 2014, 85, 165-172. [CrossRef]

36. Idris, S.S.; Rahman, N.A.; Ismail, K.; Alias, A.B.; Rashid, Z.A.; Aris, M.J. Investigation on thermochemical behaviour of low rank Malaysian coal, oil palm biomass and their blends during pyrolysis via thermogravimetric analysis (TGA). Bioresour. Technol. 2010, 101, 4584-4592. [CrossRef] [PubMed]

37. Mishra, R.K.; Mohanty, K.; Wang, X. Pyrolysis kinetic behavior and Py-GC-MS analysis of waste dahlia flowers into renewable fuel and value-added chemicals. Fuel 2020, 260, 116338. [CrossRef]

38. Yang, H.; Yan, R.; Chen, H.; Zheng, C.; Lee, D.H.; Liang, D.T. In-depth investigation of biomass pyrolysis based on three major components: Hemicellulose, cellulose and lignin. Energy Fuels 2006, 20, 388-393. [CrossRef]

39. Yang, H.; Yan, R.; Chen, H.; Lee, D.H.; Zheng, C. Characteristics of hemicellulose, cellulose and lignin pyrolysis. Fuel 2007, 86, 1781-1788. [CrossRef]

40. Nasser, R.A.; Salem, M.Z.M.; Al-Mefarrej, H.A.; Abdel-Aal, M.A.; Soliman, S.S. Fuel characteristics of vine prunings (Vitis vinifera L.) as a potential source for energy production. BioResources 2014, 9, 482-496. [CrossRef]

41. Aboulkas, A.; Hammani, H.; El Achaby, M.; Bilal, E.; Barakat, A.; El Harf, K. Valorization of algal waste via pyrolysis in a fxed-bed reactor: Production and characterization of bio-oil and bio-char. Bioresour. Technol. 2017, 243, 400-408. [CrossRef]

42. Domingues, R.R.; Trugilho, P.F.; Silva, C.A.; de Melo, I.C.N.A.; Melo, L.C.A.; Magriotis, Z.M.; Sánchez-Monedero, M.A. Properties of biochar derived from wood and high-nutrient biomasses with the aim of agronomic and environmental benefits. PLOS ONE 2017, 12, e0176884. [CrossRef]

43. Melo, L.C.A.; Coscione, A.R.; Abreu, C.A.; Puga, A.P.; Camargo, O.A. Influence of pyrolysis temperature on cadmium and zinc sorption capacity of sugarcane straw-derived biochar. BioResources 2013, 8, 4992-5004. [CrossRef]

44. Wu, W.; Yang, M.; Feng, Q.; McGrouther, K.; Wang, H.L.; Lu, H.H.; Chen, Y.X. Chemical characterization of rice straw-derived biochar for soil amendment. Biomass Bioenerg. 2012, 47, 268-276. [CrossRef]

45. Ray, A.; Banerjee, A.; Dubey, A. Characterization of biochars from various agricultural by-products using FTIR spectroscopy, SEM focused with image processing. IJAEB 2020, 13, 423-430. [CrossRef]

46. Zhou, D.; Zhang, L.; Zhang, S.; Fu, H.; Chen, J. Hydrothermal liquefaction of macroalgae Enteromorpha prolifera to bio-oil. Energy Fuels 2010, 24, 4054-4061. [CrossRef]

47. Abnisa, F.; Arami-Niya, A.; Daud, W.M.A.W.; Sahu, J.N. Characterization of bio-oil and bio-char from pyrolysis of palm oil wastes. Bioenergy Res. 2013, 6, 830-840. [CrossRef]

48. Aldobouni, I.A.; Fadhil, A.B.; Saied, I.K. Conversion of de-oiled castor seed cake into bio-oil and carbon adsorbents. Energy Source Part A 2015, 37, 2617-2624. [CrossRef]

49. Fadhil, A.B. Evaluation of apricot (Prunus armeniaca L.) seed kernel as a potential feedstock for the production of liquid bio-fuels and activated carbons. Energy Convers. Manag. 2017, 133, 307-317. [CrossRef]

50. Haarlemmer, G.; Guizani, C.; Anouti, S.; Deniel, M.; Roubaud, A.; Valin, S. Analysis and comparison of bio-oils obtained by hydrothermal liquefaction and fast pyrolysis of beech wood. Fuel 2016, 174, 180-188. [CrossRef]

51. Zadeh, Z.E.; Abdulkhani, A.O.; Saha, B. Recent insights into lignocellulosic biomass pyrolysis: A critical review on pretreatment, characterization, and products upgrading. Processes 2020, 8, 799. [CrossRef]

52. Naik, D.K.; Monika, K.; Prabhakar, S.; Parthasarathy, R.; Satyavathi, B. Pyrolysis of sorghum bagasse biomass into bio-char and bio-oil products. J. Thermal Anal. Calorim. 2017, 127, 1277-1289. [CrossRef]

53. Jouad, E.M.; Allain, M.; Khan, M.A.; Bouet, G.M. Structural and spectral studies of thiosemicarbazones derived from 3-furaldehyde and 3-(2-furyl)prop-2-enal. J. Mol. Struct. 2002, 604, 205-209. [CrossRef] 
54. Caputo, F.; Vignoli, T.; Maremmani, I.; Bernardi, M.; Zoli, G. Gamma hydroxybutyric acid (GHB) for the treatment of alcohol dependence: A Review. Int. J. Environ. Res. Public Health 2009, 6, 1917-1929. [CrossRef]

55. Chung, J.H.; Choi, S.Y.; Kim, J.Y.; Kim, D.H.; Lee, J.W.; Choi, J.S.; Chung, H.Y. 3-Methyl-1,2-cyclopentanedione down-regulates age-related NF-кB signaling cascade. J. Agric. Food Chem. 2007, 55, 6787-6792. [CrossRef]

56. Samanta, A.K.; Pandey, P.; Bandyopadhyay, B.; Mukhopadhyay, A.; Chakraborty, T. Intra- and intermolecular H-bond mediated tautomerization and dimerization of 3-methyl-1,2-cyclopentanedione: Infrared spectroscopy in argon matrix and $\mathrm{CCl}_{4}$ solution. J. Mol. Struct. 2011, 994, 97-103. [CrossRef] 